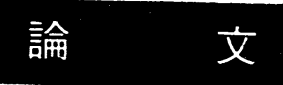

\title{
Structural Recovery of Ferrite Suspensions
}

\author{
Hiroyuki Kanai and Takeshi Amari \\ Graduate School of Science and Technology, Chiba University, \\ 1-33 Yayoi-cho, Chiba 260, Japan
}

\begin{abstract}
In order to investigate the structural recovery of suspension of acicular $\gamma$-ferrite powder in mineral oil, viscoelastic properties were measured intermittently with small amplitude oscillatory shearing (strain at $0.3 \%$, rate at $10 \mathrm{rad} / \mathrm{sec}$ ). A couette test fixture was used for the measurements. Storage and loss moduli of the suspension immediately after cessation of large amplitude oscillatory preshearing (strain at 50-500\%, rate at $50 \mathrm{rad} / \mathrm{sec}$, for $20 \mathrm{~min}$ ) increased with increasing strain amplitude of preshearing. The moduli of the suspension at the early stage of recovery were found to follow the scaling equation:

$G^{\prime}\left(\right.$ or $\left.G^{\prime \prime}\right) \sim t^{n}$
\end{abstract}

where $t$ is resting time after cessation of preshearing. The moduli decayed after reaching the maximum, when larger amplitude preshearing had been applied.

The phenomenon is interpreted from the view point of percolation using a two level (intra- and interfloc level) network model of flocculated suspensions.

Key words: Flocculated suspension / Network model / Percolation / Ferrite / Structural recovery

\section{酸化 鉄懸 濁液の構 造 回復}

\author{
金井 宏行 ${ }^{*} \cdot$ 甘利 武司 ${ }^{*}$
}

（原稿受理：1991年 7 月 8 日）

\section{1. 緒 言}

酸化鉄の繋濁液は，磁気記録媒体（例えば，録音用テープ）の 製造工程中で中間原料として調製され，ベースフィルム上に狳布 される.このため工業上の要請から流動特性が研究されてきた。 粒子の保持する磁気的性質により，きわめて「凝集性」が強く， チキソトロピー, 擬塑性流動等の凝集性懸濁液に特徵的な流動特 性が，明瞭に観測される。

凝集性の微粒子濃厚懸濁液が，特異的なレオロジー挙動を示す ことは, よく知られている. 粒子間に引力が㗢くとき, 粒子の連 鎖による網目構造が生成し, 粒子濃度が十分大きければ網目が系 全体を覆らようになる。この網目構造はせん断を加えれば崩壊し, 静置すれば再構成する．このような懸濁液の構造回復, すなわち 外力を受けた後の静置下での凝集構造の回復は, 凝集性の懸濁液 の基本的な特性と考光られる. しかし, 静置下の凝集挙動は, 定 常流動下での凝集構造の崩壊, 再凝集挙動（例兄ば, レオペクシ 一)に比べて，あまり詳しくは調べられていない。

\footnotetext{
*千葉大学大学院自然科学研究科 $\overline{\mathbf{T}} 260$ 千葉市弥生町 $1-33$
}

Sohm ら ${ }^{1)}$ は，ナトリウムモンモリロナイトの懸濁液の貯蔵弾 性率の回復举動を調べ, 以下の型の式を適用した。

$$
G^{\prime}(t)=G_{\mathrm{E}}^{\prime}(1-\exp (-A t))
$$

式中 $t$ は静置時間, $A$ は回復の速度定数, $G^{\prime}{ }_{\mathrm{E}}$ は貯蔵弾性率 $G^{\prime}$ ( $t$ )の平衡值を表す.

本研究では，酸化鉄懸濁液にせん断を印加して初期構造を破壊 し, その後の構造回復を, 微少なひずみを用いた複素弾性率測定 によって観察した。この結果, 酸化鉄懸濁液の貯蔵弾性率の回復 には式(1)が適用されなかった。 この回復挙動について, 構造モデ ルを導入し説明を試みた。

\section{2. 実 験}

本研究では録音用テープ等に用いられる軸比 (軸長/軸径) 10 , 軸長 $0.4 \mu \mathrm{m}$ の針状磁性酸化鉄 $\left(\gamma-\mathrm{Fe}_{2} \mathrm{O}_{3}\right)$ を用いた。懸濁液の 調製は以下の手順で行った. 上記酸化鉄粉 $100 \mathrm{~g}$ と界面活性剂 Gafac RE610 (GAF 製) ${ }^{2)} 5 \mathrm{~g}$ をメチルェチルケトン $300 \mathrm{~g}$ 中で 混合する．遠心法により酸化鉄を溶液から分離し回収する．これ を新たに $300 \mathrm{~g}$ のメチルェチルケトン中に投入し, 再度遠心法で 
分離する，同じ操作をもら一度行い，酸化鉄粉に吸着されない余 剩の界面活性剂を除去する。こうして表面改質した酸化鉄粉を常 温で減圧乾燥した後，ボールミルを用いて鉣油 (0.135 Pa・s (30 $\left.{ }^{\circ} \mathrm{C}\right)$ ) 中に分散し，懸濁液を得た。

同じ酸化鉄を熱処理 $\left(500^{\circ} \mathrm{C} ， 6\right.$ 時間) によって非磁性化した 試料 $\left(\alpha-\mathrm{Fe}_{2} \mathrm{O}_{3}\right)$ も用意し，同様にして懸濁液を調製した。

眊濁液の粘弾性測定には，レオメトリックス・ダイナミック・ スペクトロメーター（レオメトリックス社）を用いた。 測定は二

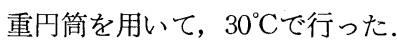

\section{3. 結 果}

懸濁液を二重円筒に装填し, 強いせん断（例光ば, ひずみ振幅

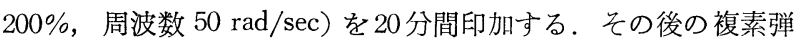
性率の変化をひずみ振幅 $0.3 \%$ ，周波数 $10 \mathrm{rad} / \mathrm{sec} て ゙$ 間欠的に測 定し追跡した.

この結果, せん断 (以下, プレシェア) 印加後の複素弾性率の 回復挙動が, 本研究の酸化鉄㲘濁液の場合には, プレシェアのひ ずみ振幅に強く依存することが分かった。

Fig. 1 飞 $33 \mathrm{wt} \%$ (分散剤を含む) の磁性酸化鉄懸濁液につい ての結果を示すフプレシェアのひずみ振幅が小さい（<100\%)
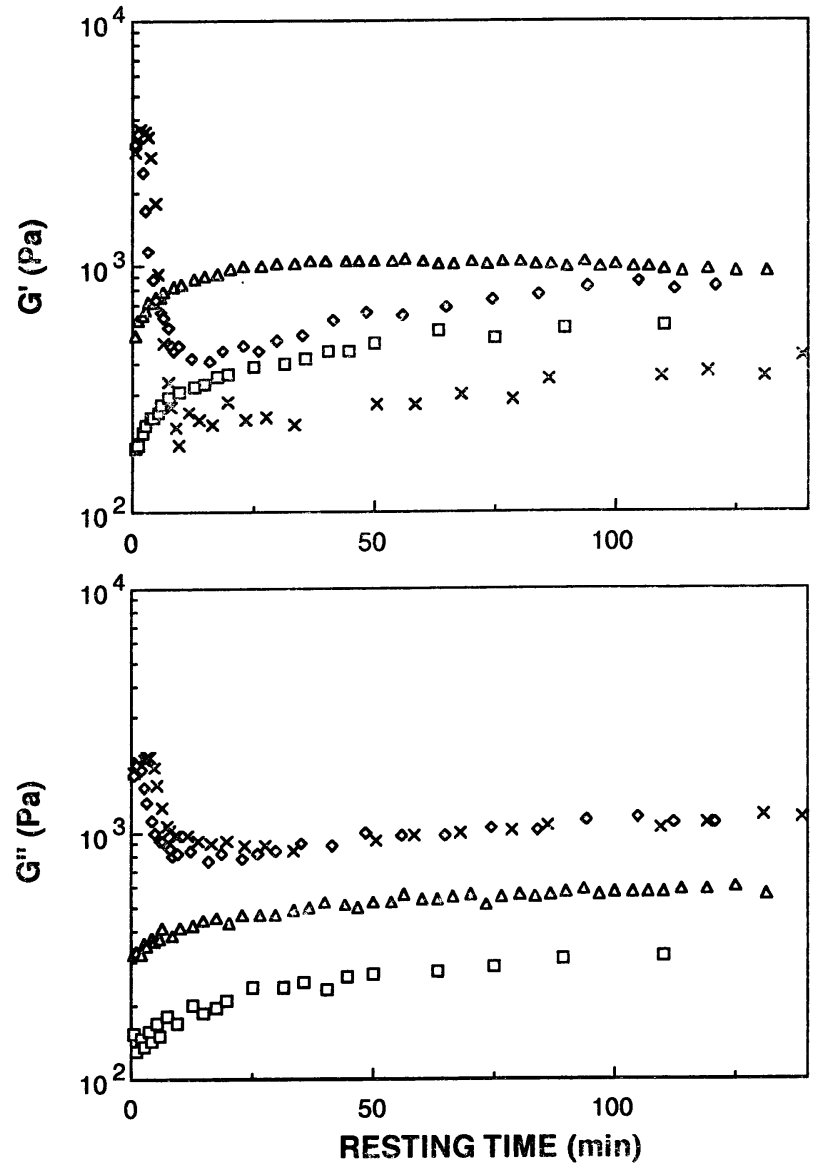

Fig. 1 Time dependence of $G^{\prime}$ and $G^{\prime \prime}$ for $\gamma$-ferrite suspension $(33 \mathrm{wt} \%)$ in mineral oil after cessation of preshearing.

Strain amplitude of preshearing : $50 \%(\square), 100 \%$ $(\triangle), 200 \%(x), 500 \%(\diamond)$
場合, せ九断印加停止後の懸濁液の $G^{\prime}, G^{\prime \prime}$ とも単調に増加する. しかし，プレシェアのひずみ振幅が大きくなるに従って（100〜 500\%)，プレシェア停北直後から $G^{\prime}, G^{\prime \prime}$ とも大きな值を示すよ らになり，またこれらの回復曲線は途中から顕著な減衰を示すこ とが観測された。プレシェアの周波数は $50 \mathrm{rad} / \mathrm{sec}$ を用いた. $25 \mathrm{wt} \%$ の磁性酸化鉄懸濁液（分散媒での希釈によって調製） について，同じ試験を行った (Fig. 2). 複素弾性率の回復曲線に $33 \mathrm{wt} \%$ の場合と同様のプレシェア依存性が観察されたが，極大 をとっての減衰は $33 \mathrm{wt} \%$ の鲧濁液ほど顕著ではない。

非磁性の酸化鉄懸濁液 $(33 \mathrm{wt} \%)$ についても同様な試験を行 った結果, 磁性懸濁液に類似な回復挙動が観察された (Fig. 3). すなわち，プレシェアのひずみ振幅が大きいほど，やはり回復初 期に複素弾性率の絶対值が大きく，また特にプレシェアのひずみ 振幅が大きい場合 $(500 \%)$, 回復曲線は極大をとって減少に転ず る。これは，現象が磁性懸濁液に特異的なものではなく，他の懸 濁液系でも起こり得ることを示す結果と思われる。しかし，非磁 性懸濁液では磁性懸濁液の場合ほど際だったプレシェア依存性が 現われていないことから，粒子間の磁気的相互作用は，この現象 の発現に寄与する方向で作用すると考学られる.
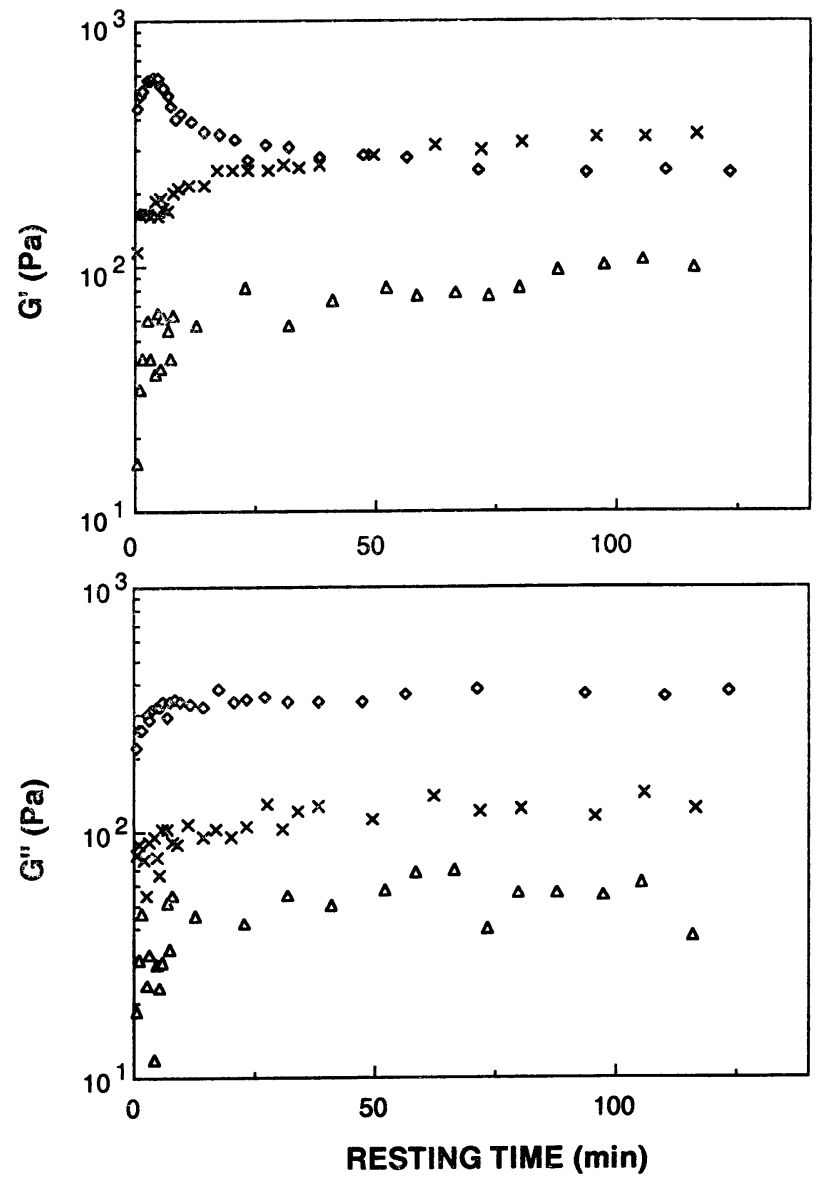

Fig. 2 Time dependence of $G^{\prime}$ and $G^{\prime \prime}$ for $\gamma$-ferrite sus. pension $(25 \mathrm{wt} \%)$ in mineral oil after cessation of preshearing.

Strain amplitude of preshearing : $100 \%(\triangle), 200 \%$ $(x), 500 \%(\diamond)$ 

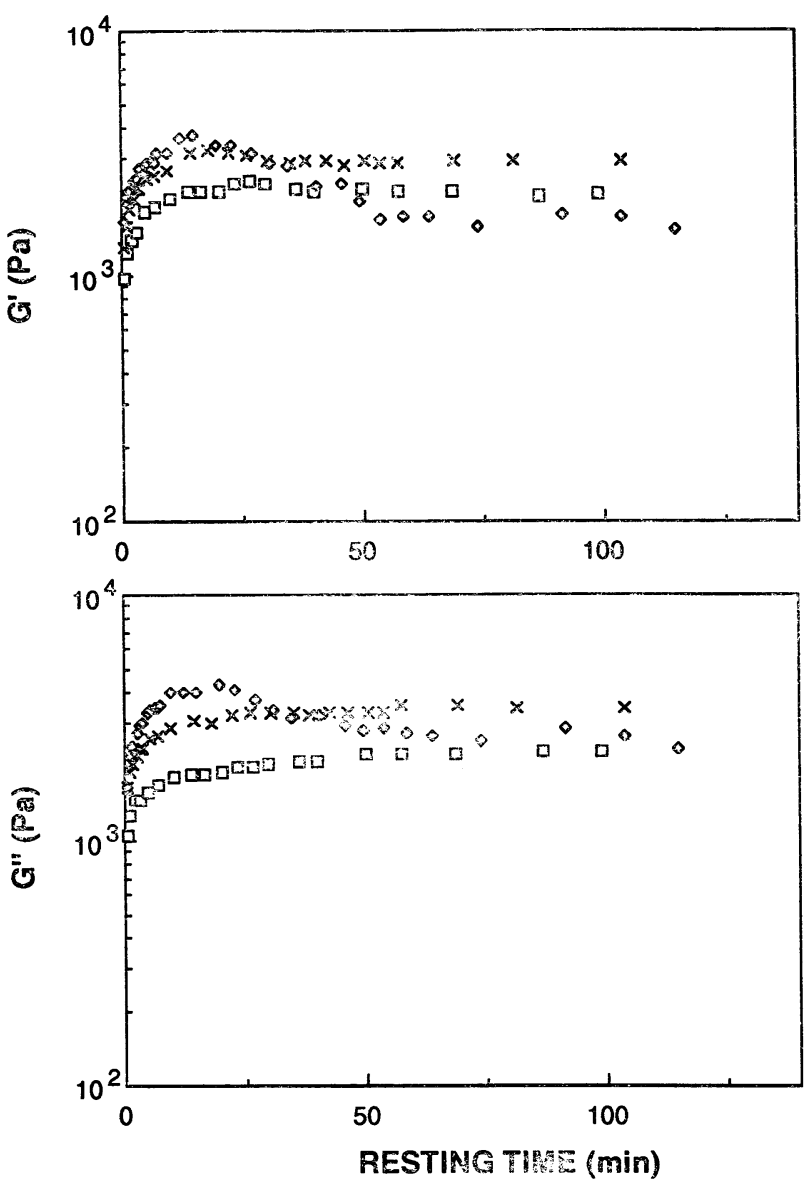

Fig. 3 Time dependence of $G^{\prime}$ and $G^{\prime \prime}$ for $\alpha$-ferrite suspension $(33 \mathrm{wt} \%)$ in mineral oil after cessation of preshearing.

Strain amplitude of preshearing : $50 \%(\square]), 200 \%$ $(\times), 500 \%(\diamond)$

\section{4. 考察}

\section{$4 \cdot 1$ 構造回復挙動}

愳濁液の構造回復が，レオロジーの測定によって検討された例 としては, 酸化チタン, Laponite-RD, Gelwhite H, Bauxite residue, アルミニウム石險，カーボンブラック懸濁液等について の報告があるが，いづれも弾性率はせん断印加後の時間経過に伴

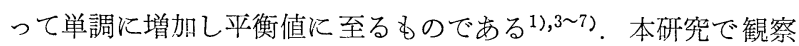
した酸化鉄懸濁液では, 複菜弾性率の回復が極大值を示して減少 に転ずる場合もあり，これらの系とは異なっている。また，本実 験で極大値をとらなかった，例えば，磁性懸濁液 $33 \mathrm{wt} \%$ の系 にひずみ振幅 $50 \%$ のプレシェアを与えた場合の複素弾性率の回復 過程 (Fig. 1) についても，式(1)は適用できなかった。構造回復 の過程は, Fig. 4〜6 の両対数プロットに見られる依存性によっ て明らかなように，むしろ次式のような規則に従う。

$$
G^{\prime}\left(\text { or } G^{\prime \prime}\right) \sim t^{\text {n }}
$$

ここで, $t$ はプレシェア停止後の静置時間, 指数 $n$ は, 本研究の

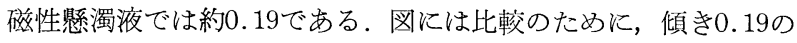
平行線を書き添えた。興味深いことに，極大值を持つ回復曲線に ついても，初期の立ち上がりの部分には同じ式(2)の依存性が観察
される，非磁性の懸濁液の場合 (Fig. 6) 飞も，磁性懸濁液と同 様な回復過程が認められる。

一方，構造回復のプレシェアひずみ振幅への依存性については， 報告された例が少ない。しかし, 本研究の懸濁系が強いせん断を 与えるほど回復初期の弾性率が高くなるのに対して, むしろ逆の 傾向を示す場合8のほうが一般的と思われる。すなわち，本実験 の懸濁系に扔いては，プレシェアにより弾性率の低下を起こすよ うな「通常の構造変化過程」に加え, せん断によって高い弾性率 の付与される「特異的な構造变化過程」の有ることが予想される.

\section{$4 \cdot 2$ 構造回復のモデル}

以上の結果から次のような構造モデルを想定することができる. 本実験の懸濁液の棈造破壊拈よび回復挙動は, floc 内部の網目 構造と, 系全体にわたる floc-floc 網目構造の二段階からなる構 造モデルによって，説明することが可能である．

Step 1 強いせん断のもとでの floc 構造の再構成

䀣濁液は強いせん断の下で, 独立した floc からなる島構造を 形成する。一般にせん断によって構造がより小さな榊造単位に分 断を受けるときには, 構造単位の間に取り込んでいた分散媒を放 すため, 凝集相の体積分率は減少し (Fig. 7(a)), この結果とし て例党ば粘性が低下する。本研究の懸濁系ではこのような「チキ ソトロピックな」過程の他に, 以下のような floc 内部構造の
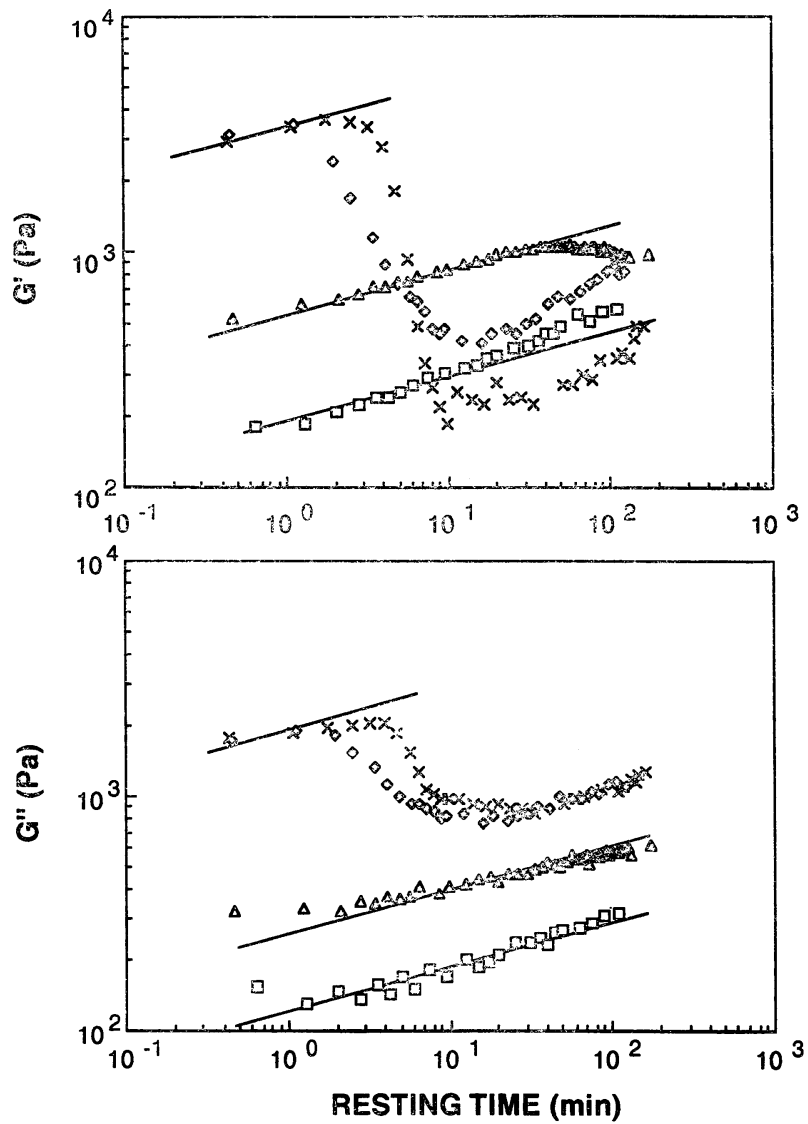

Fig. 4 Double logarithmic plots of $G^{\prime}$ and $G^{\prime \prime}$ against resting time for $\gamma$-ferrite suspension (33 wt \%) in mineral oil after cessation of preshearing. Strain amplitude of preshearing : $50 \%(\square), 100 \%$ $(\triangle), 200 \%(\times), 500 \%(\diamond)$ 

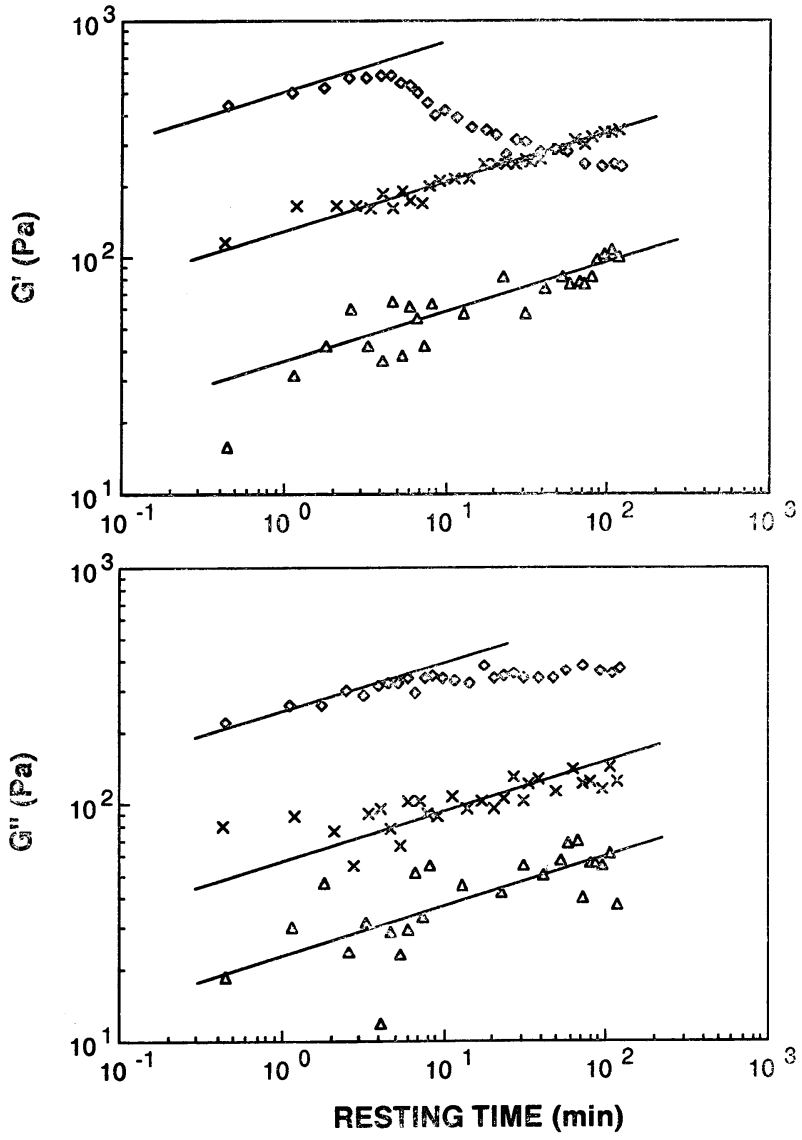

Fig. 5 Double logarithmic plots of $G^{\prime}$ and $G^{\prime \prime}$ against resting time for $\gamma$-ferrite suspension (25 wt\%) in mineral oil after cessation of preshearing. Strain amplitude of preshearing : $100 \%(\triangle), 200 \%$ $(\times), 500 \%(\diamond)$

（「針状粒子」の凝集体の特性とも考えられる）再構成過程を仮定 した.

floc がせん断によって分断, 破壊される過程で, floc 内部の 構造（一次粒子の形成する構造）の分断が進み, floc は膨れた (loose な) 状態になる。このような構造変化の結果, 系全体の体 積分率はせん断の印加によりむしろ大さくなる (Fig. 7(b)). その 一方で, floc 弾性の起源である粒子間結合の密度は小さくなるの で，各 floc 固有の弾性率は低下する.

step 2 せ九断停止直後の floc-floc 結合網目の形成 floc 間結合による網目構造は，せ九断停止の直後に直ちに形成 される，この時点で系全体を覆う網目構造の骨組み (floc 網目) が決まる。

floc を構造単位とする「弾性パーコレーション」のモデル99 (Fig. 8(b)) を仮定すれば，この時点での懸濁液の貯蔵弾性率 $G_{0}^{\prime}$ は, floc phase（凝集相）の特性と式(3)のよ5に関係づけられる (損失弾性率 $G^{\prime \prime}{ }_{0}$ に関しても貯蔵弾性率と同様な関係 ${ }^{10}$ ) が得られ る).

$$
G_{0}^{\prime}=K\left(f_{0}-f_{\mathrm{c}}\right)^{\mathrm{d}}
$$

ここで，Kは Fig. 8(b) そ乱ける骨組みの要素の弾性率に関係す る係数であり，このモデルでは floc 間結合の弾性率, すなわち floc の弾性率に比例する係数と考えることができる． $f_{0}$ はせん
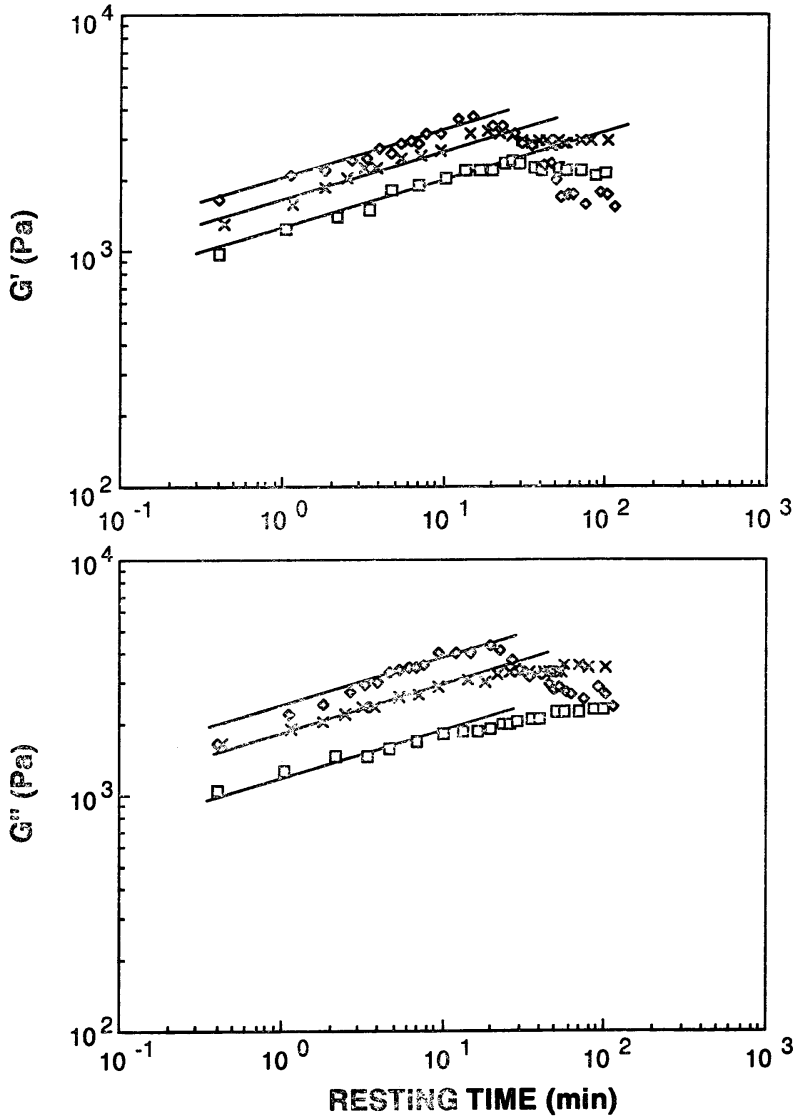

Fig. 6 Double logarithmic plots "of $G^{\prime}$ and $G^{\prime \prime}$ against resting time for $\alpha$-ferrite suspension (33 wt\%) in mineral oil after cessation of preshearing. Strain amplitude of preshearing : $50 \%(\square), 200 \%$ $(x), 500 \%(\diamond)$

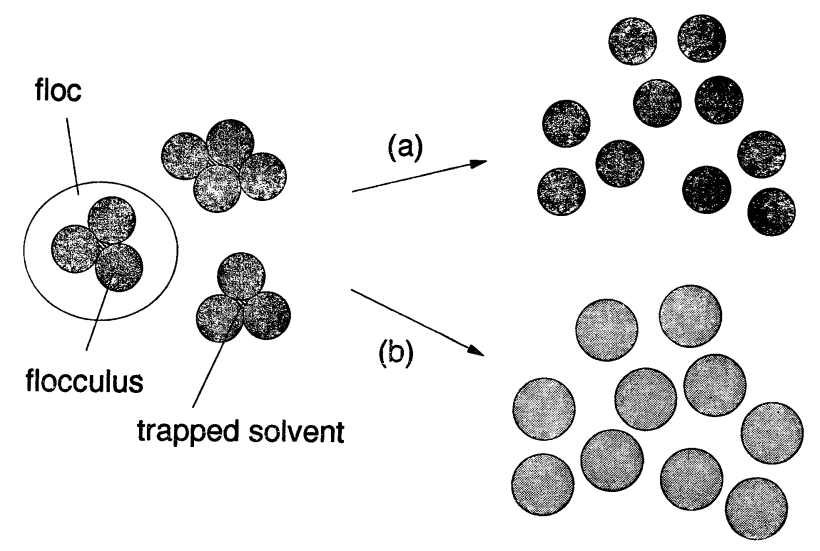

Fig. 7 Schematic representation for structural change of suspension under shear.

Structural breakdown of flocs into smaller units (flocculi) releasing the trapped solvent (a).

Structural breakdown of flocs into flocculi and loosening of the flocculi under shear(b).

断停止直後の floc phase の体積分率, $f_{\mathrm{c}}$ は percolation threshold, に相当する floc phase の体積分率， $d$ は網目構造の特性に依存す る指数 ${ }^{11) て ゙ あ る 。 ~}$

step 1 のようなfloc 構造の仮定の下で, 式(3)の貯蔵弾性率 $G_{0}^{\prime}$ 
に対し、「プレシェアによる floc phase の弾性率減少」, すなわ ちKの減少の效果が，「プレシェアによるfloc phase の体積分率 $\left(f_{0}\right)$ の增加」の效果に比べて小さいならば， $G_{0}^{\prime}$ の值は本実験の 結果のようにプレシェアのひずみ振幅の大きい注ど大きくなり得 る.

step 3 静置下に拈汀る弾性率の構造回復と floc phase の収縮 網目の骨組みが形成された後の floc phase 内部の構造変化は, 網目構造の骨組み要素の性質の変化として扱うことができる. floc phase 内部で粒子同士の結合が進むに従い，骨組み要素の弹 性は次第汇高くなる。一方で，floc phase の体積分率は減少する。

プレシェアが比較的小さい場合, 構造回復過程での floc phase の体積変化はあまり大きくないので, 初期の骨組み構造は最後ま であまり変化しない（Fig．8(c))，このとき系の弾性率は，単調 に增加する。

網目構造形成時の「弾性 percolation」の式(3) 飞括いて， $K$ は floc phase の弾性率, 残りの部分は骨組み構造の構造因子と考兄 ることができる。それぞれを時閒の関数と考えれば，次式のよう になる。

$$
G^{\prime}(t)=K(t) M(t)
$$

$M(t)$ は骨組みの構造因子を表す。 $t$ が小さいときに, 式(4)は 式(3)に一致する.

プレシェア直後の系の貯蔵弾性率の回復が floc 内部の粒子網 目構造の弾性率変化に対応すると考光れば, Fig. 4 亿示された結

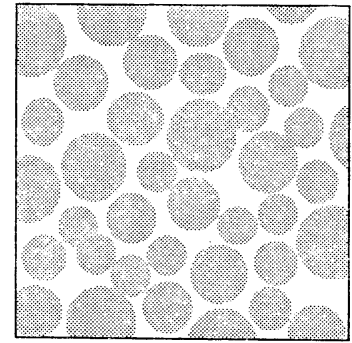

(a)

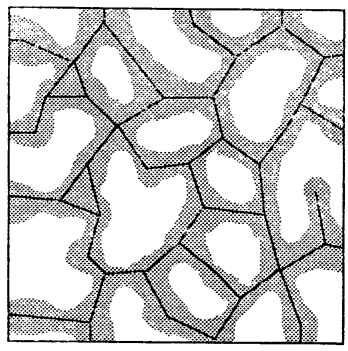

(c)

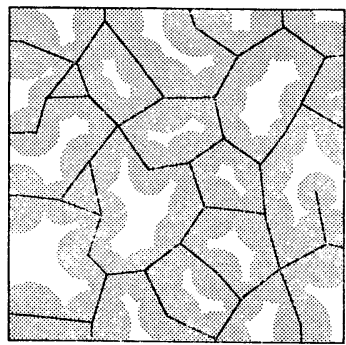

(b)

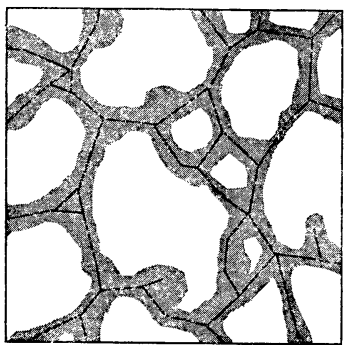

(d)
Fig. 8 Schematic representation for network formation and alteration in ferrite suspension.

Floc structure under shear(a). Network structure immediately after cessation of the preshearing; a percolation model(b). Shrinkage of floc phase due to progress of intrafloc particle linkages in a backbone structure(c). Further shrinkage of floc phase with breakdown of the backbone into a different configuration(d).
果から以下の関係が推測される.

$$
K(t)=k_{0} t^{\mathrm{n}}
$$

$k_{0}$ はこの場合, floc phase の初期状態に依存する.

一方，プレシェアのひずみ振幅が大きい場合（例えば，Fig. 4 でプレシェアのひずみ振幅が200\%拈よび500\%のとき）には，弾 性率の回復過程での floc phase の収縮も大きく, 初期の骨組み構 造が維持できなくなり，構造の分断が生じる (Fig. 8(d)).

Fig. 1 で観察された $G^{\prime}$ 抢よび $G^{\prime \prime}$ の急峻な減少は, このよう な網目構造の崩壞によるという解釈が可能と思われる。ここでの 弾性率の変化は, 式(4)ではMの項の変化に対応する.

急速に減少した $G^{\prime}$ 扣よび $G^{\prime \prime}$ は, 極小值をとって再び増加に転 じる. その勾配は Fig. 4 に見られるよ5に, 回復初期の勾配に 近い。すなわち, 再びここに括ける構造回復が初期と異なる骨組 み構造の上での floc phase 内部の構造回復（式(5)）であることを 示唆すると考えられる.

懸濁液濃度による回復挙動の違い (Fig. 2) は, 一つにはプレ シェアの実質的な效果の違いによると思われる。懸濁液の濃度が 高ければ，それだけプレシェアのひずみは系中の個々のflockよ く伝達されるので，同じひずみ振幅によっても floc をより loose にし易く，これによりせん断の效果を強く現わすことが予想され る.

また, 非磁性懸濁液の構造回復が磁性䯚濁液ほど際だったプレ シェア依存性を示さなかった（Fig. 3) ことから，磁性䋰濁液の floc phase は, 非磁性の懸濁液の場合に比ベプレシェアによって 大きな構造変化（体積変化）を生じていると推測される. 静置下 で磁性懸濁液の floc phase がより密度の高い構造にまで収縮して 安定化することにより，プレシェアで構造が緩んだときとの体積 差が非磁性の系よりも大きくなるためではないかと思われる。

\section{5. 結言}

酸化鉄鲧濁液の構造回復に伴 5 弾性率の变化を, 二段階からな る構造モデルによって定性的に説明した。

本研究の懸濁系の場合, 懸濁粒子が針状であることが一つの特 徵である．針状粒子は球状の粒子よりも loose な（広がった）凝 集構造を形成しやすいと思われ, 本研究で観察されたような弾性 率のプレシェア依存性を構造的に生じやすいことが考穴られる。 また，磁性を有する酸化鉄の懸濁液の方が非磁性のものよりも現 象の発現がより劇的であったことから, 本研究で見いだされた現 象が針状磁性粉懸濁液に特異的なものである可能性もある。これ についての実験，検証を現在検討中である.

(平成 2 年10月26日第38回レオロジー討論会にて発表)

謝辞 本研究の試料調製にあたり協力いただいた花王㑣情報科 学研究所に感謝する.

\section{文献}

1) Sohm R, Tadros ThF, J. Colloid Interface Sci,. 132, 62 (1989).

2) Dasgupta S, J. Colloid Interface Sci., 124, 22 (1988).

3) Zosel A, Rheol. Acta, 19, 737 (1982).

4) Ramsey JDF, J. Colloid Interface Sci., 109, 441 
(1986).

5) Nguyen QD, Boger DV, Rheol. Acta, 24, 427 (1985).

6) Roscoe R, Rheol. Acta, 19, 737 (1980).

7）渡辺鋼市郎, 中根喜則, 甘利武司, 日本レオロジー学会誌, 16, 15 (1988).

8) Mewis J, de Bleyser R, J. Colloid Interface Sci., 40,
360 (1972).

9）金井宏行，塗装工学， 24，335 (1989).

10) Winter HH, Progr. Colloid \& Polymer Sci., 75, 104 (1987).

11) Woignier T, Phalippou J, Sempere R, Perous J, J. Phys. France, 43, 283 (1988). 